\title{
AKUMULACJA PIERWOTNA I CZASOWOŚCI KAPITALIZMU
}

\author{
JOANNA BEDNAREK
}

\begin{abstract}
Abstrakt: Artykuł broni tezy, że w obrębie kapitalizmu da się wyróżnić wiele wzajemnie niespójnych czasowości oraz że analiza kapitalizmu przez pryzmat akumulacji pierwotnej umożliwia dokładniejsze ujęcie sposobu jego funkcjonowania, uwzględniające złożoność związana z interakcjami wspomnianych czasowości. Zagadnienie akumulacji pierwotnej jest, jak dowodzi Sandro Mezzadra, dobrym punktem wyjścia dla analizy tego kompleksu problemów. Pozwala bowiem postawić dwa pytania: o relację między historycznym wymiarem a strukturalną logiką kapitalizmu oraz o hierarchiczna relację między centrum i peryferiami systemu kapitalistycznego. Pomocny okazuje się tu projekt „,sprowincjonalizowania Europy”, zaproponowany przez Dipesha Chakrabarty'ego; jest to próba zdekonstruowania kategorii takich jak postęp, modernizacja, czy kapitał jako taki z jego abstrakcyjną struktura.
\end{abstract}

Słowa kluczowe: akumulacja pierwotna, kapitalizm, historia, Dipesh Chakrabarty, Massimiliano Tomba 


\section{Akumulacja pierwotna - między marginesami a centrum kapitalizmu}

„Zechce Pan łaskawie wskazać swej małżonce jako rozdziały przede wszystkim nadające się do czytania: rozdział o »dniu roboczym«, »Kooperacja, podział pracy i maszyny«, wreszcie o »pierwotnej akumulacji«" (Marks 1950, 48). Oto zawarte w liście do Ludwika Kugelmana z 30 listopada 1867 roku wskazówki Marksa dotyczące najlepszego początku przygody czytelniczej z Kapitałem. Najlepiej, jak widzimy, zaczać od rozdziałów historycznych, empirycznych nieprzeładowane teoria, z pewnością nie sprawią trudności damie ${ }^{1}$.

Czy jednak rozdziały te, a przede wszystkim rozdział o akumulacji pierwotnej, rzeczywiście należą do porządku historycznego lub też anegdotycznego?

W 24. rozdziale Kapitatu Marks zauważa: „początek akumulacji objaśnia się nam w ten sposób, że się o nim opowiada jako o anegdocie historycznej” (Marks 1968, 848). Chodzi, ściślej, o „anegdotę” stanowiącą narrację założycielską ekonomii klasycznej: „na początku” jedni byli pracowici i skłonni do oszczędzania, inni nie - oszczędności tej pierwszej grupy jednostek miały stać się podstawa późniejszej akumulacji. Marks będzie dążył do zastapienia tego mitu założycielskiego narracją krytyczną². Zakłada to jednak nie tylko inne treści (przemoc i wywłaszczenia zamiast pracy i oszczędności), ale i zmianę płaszczyzny, na której stawia się problem $^{3}$ : zamiast linearnej narracji historystycznej stykamy się z „transcendentalnym” pytaniem o warunki możliwości akumulacji kapitalistycznej w sensie tyleż historycznym, co strukturalnym. Jak stwierdza Sandro Mezzadra: „zainteresowanie Marksa historią („prehistoria”) kapitalistycznego sposobu produkcji nie ma w sobie nic »antykwarycznego«" (Mezzadra 2014, 47). Akumulacja pierwotna nie stanowi odpowiedzi na historystyczne pytanie „jak to się zaczęło?”, ale rozwiązanie problemu, jaki przysparza cykliczny charakter akumulacji kapitalistycznej zrekonstruowany w I tomie Kapitału: konieczne staje się założenie momentu „prehistorii”, stwarzającego wolną pracę i wolny kapitał, które umożliwią tę akumulację (Marks 1968, 848).

Rozwiązanie tego konkretnego problemu daje jednak początek kolejnym, które rodzi przede wszystkim fakt, że rozdział o akumulacji pierwotnej to zarąem narracja historyczna i konstrukcja logiczna (por. Althusser i Balibar 1975, 24). Nie będzie tu jednak, jak w Cazytaniu „Kapitału”, chodzić o „problem przejścia” między jednym sposobem produkcji a drugim; wręcz

\footnotetext{
${ }^{1}$ Seksistowski wydźwięk tej uwagi jest w raczej efektem nieszczęśliwego zbiegu okoliczności niż złych intencji Marksa (co nie znaczy, by w kwestii kobiecej miał on na ogół bezsprzecznie dobre intencje).

${ }^{2}$ Marks chce więc zastąpić burżuazyjny mit o początku genealogią - co nie znaczy, że chce po prostu zastapić mit „prawdą". Mit ów jest bowiem (podobnie jak fetyszyzm towarowy) „obiektywnie prawdziwy” w sensie skuteczności. Dlatego, jak ujmuje to Tomba, w projekcie Marksowskiej krytyki nie chodzi po prostu o zastapienie mniej obiektywnej wiedzy wiedzą bardziej obiektywną, ale o stworzenie wiedzy całkowicie nowego rodzaju; obiektywność mityczna, przesłaniającą interesy klasowe zasłoną obiektywności, chce zastąpić wiedza upolityczniona, interweniującą w rzeczywistość (Tomba 2013, 110-112).

${ }^{3}$ Zmianę, jak by powiedzieli Althusser i Balibar, problematyki.
} 
przeciwnie ${ }^{4}$. Akumulacja pierwotna pozwala - jak podkreślają Sandro Mezzadra i Massimiliano Tomba - ujrzeć w nowym świetle właśnie normalne funkcjonowanie kapitalistycznego sposobu produkcji. Zdaniem obu teoretyków problem akumulacji pierwotnej jest kluczowy dla ujęcia tego, jak właściwie funkcjonuje kapitalizm, zarówno jako sposób produkcji, jak i jako abstrakcja określona (Mezzadra 2014, 37). Zagadnienie, którego dotyczy niniejszy tekst, jest więc natury zarazem przedmiotowej i metodologicznej. Łączy refleksję nad sposobem analizy kapitalizmu, czy może raczej faktycznie istniejącej formacji społecznej, w której dominują kapitalistyczne stosunki produkcji (zwłaszcza pod kątem relacji między centrum i peryferiami systemu kapitalistycznego), z pytaniem o sposób ujmowania kapitalizmu jako pojęcia - ściślej, z pytaniem o to, jak mamy w jego obrębie konceptualizować relację między logiką a historia, między tym, co uniwersalne i tym, co partykularne, między pojęciem a empirią ${ }^{5}$. Umieszczenie w centrum naszej uwagi zagadnienia akumulacji pierwotnej umożliwia wspólną artykulację obu tych wymiarów: pozwala na jednoczesne zadanie pytania o to, jak „rzeczywiście” jest ustrukturyzowany kapitalizm, i o to, jak myśleć o kapitalizmie.

Tekst składa się z trzech części. W pozostałych partiach niniejszej części omawiam problem akumulacji pierwotnej jako momentu genezy (w rozumieniu Foucaulta) struktury kapitalizmu (w rozumieniu Althusserowskim, potraktowanym jednak dość luźno). Przedstawiam też, na przykładzie stanowiska Davida Harveya, obecne we współczesnym marksizmie rozwiązanie tego problemu polegające na rygorystycznym rozróżnieniu między kapitałem (struktura, logika) a kapitalizmem (historia, empirią, konkretem).

W części drugiej przedstawiam koncepcje „dwóch historii” kapitalizmu autorstwa Dipesha Chakrabarty'ego, jako alternatywne ujęcie problemu relacji między kapitałem a kapitalizmem (czy też logiką i historia), podkreślające uwikłanie logiki („Historii 1”) w odraczające i rozbijające spójność mechanizmy historii („Historii 2”). Zestawiam też to wyrosłe z ducha dekonstrukcji ujęcie z marksistowską kategorią subsumcji. Część trzecia poświęcona jest możliwości opisu relacji między abstrakcja/logiką i empiria/historią w języku marksistowskim (w sposób inny niż ten zaproponowany przez Harveya). Opisu takiego

\footnotetext{
${ }^{4}$ Ujęcie, które proponuja Tomba i Mezzadra, nie byłoby możliwe bez rozstrzygnięć Althussera i Balibara dotyczących strukturalnego charakteru sposobu produkcji. Ma ono jednak na celu przemieszczenie i/lub zakwestionowanie wielu rozwiązań wprowadzonych w Caytaniu „Kapitatu”, takich jak rozróżnienie między sposobem produkcji (struktura) a rzeczywiście istniejącą formacją społeczną, albo rozróżnienie między dynamika a diachronia (por. Althusser i Balibar 1975, 300, 431).

${ }^{5}$ A także: między kapitałem a kapitalizmem (Harvey 2014), między sposobem produkcji a formacją społeczna (Althusser i Balibar 1975, 300). Teoria zależności (Samir Amin) i teoria systemów-światów (Immanuel Wallerstein) stawiają ten problem w nieco inny niż teorie klasycznie marksistowskie sposób, zwracając uwagę już w punkcie wyjścia na systemowy charakter powiązania między centrum i „zacofanymi”/niekapitalistycznymi peryferiami. Rozpatrzenie sposobu, w jakich modyfikują one marksistowskie rozróżnienie na kapitał i kapitalizm, wykracza jednak poza zakres niniejszego tekstu.
} 
dostarcza Massimiliano Tomba, przedstawiający uniwersalność kapitału jako wynik procesu synchronizacji.

Akumulacja pierwotna to początek kapitalizmu w podwójnym sensie: historycznym (choć nie w sensie linearnym - co będzie miało ważne konsekwencje) i zarazem logicznym. Pytamy zatem - za Althusserem (2012) - o genezę struktury, jaką jest kapitalistyczny sposób produkcji. Chodzi jednak nie o „przejście”, ale o źródło, początek w sensie genealogicznym, pojmowany jako moment wyłonienia się struktury, chwilę, jak to ujmuje Michel Foucault, „wkroczeni[a] sił na scenę” (Foucault 2000, 122). Jak uznaje Mezzadra, metoda Marksa jest w istocie metoda genealogiczną (Mezzadra 2014, 50). Kapitalistyczny sposób produkcji, oglądany „od strony” akumulacji pierwotnej, jawi się jako dynamiczna struktura, konstytuowana nie tyle przez synchroniczne elementy, co przez siły ${ }^{6}$. Moment, w którym pojawia się konfiguracja sił, nie jest wstępem do „normalnego” funkcjonowania tej struktury (dynamiki przeciwstawianej diachronii); przeciwnie, niejednoznaczność charakteryzująca to stadium będzie miała konsekwencje także dla już ukształtowanego kapitalizmu. To kontrintuicyjne interpretowanie Marksa za pomoca pojęć Nietzscheańsko-Foucaultowskich ma jednak swój cel: umożliwia pokazanie, że w przypadku kapitalizmu jako struktury nie da się oddzielić logiki od historii: pytając o jedna, zawsze pytamy zarazem o drugą.

Natura wkraczających na scenę sił również każe zadać pytanie istotne nie tylko dla teoretycznych ujęć kapitalizmu, ale również dla praktyki. Centralna dla kompleksu problemowego związanego z akumulacja pierwotną jest bowiem rola tzw. czynników pozaekonomicznych w funkcjonowaniu kapitalizmu: nie tylko przemocy, w tym przemocy państwowej, ale także relacji władzy niemających charakteru czysto klasowego - rasizmu, patriarchatu, nacjonalizmu, homofobii. Czytelnicy i czytelniczki prawdopodobnie zgodzą się bez wyjątku, że odgrywają one jakąś, często dwuznaczną, rolę w odtwarzaniu się relacji kapitalistycznych - ale prawdopodobnie trudno byłoby osiagnać konsensus co do tego, jak bardzo są ważne i w jakim właściwie pozostaja związku z tym, co istotowe dla kapitalizmu.

„Niezależnie od tego, jak istotne w historii rozwoju kapitalizmu były rasa, gender i tożsamość seksualna oraz walki toczone w ich imię, można wyobrażać sobie trwanie kapitalizmu bez nich, co nie jest możliwe w wypadku klasy" (Harvey 2011, 115). Powyższa wypowiedź Davida Harveya jest świetną ilustracją dość typowego podejścia, opierającego rozwiązanie wspomnianego problemu na rozróżnieniu na istotę i to, co przygodne albo na logikę

\footnotetext{
6 Zagadnienie akumulacji pierwotnej z zagadnieniem metody Marksa, określanej jako strukturalizm genetyczny, wiąże tė̇, w pochodzącym z 1970 roku artykule Geneza i struktura, Lucien Goldmann (Goldmann 1978) (dziękuję Katarzynie Bielińskiej za zwrócenie mi uwagi na ten tekst). Balibar również przyznaje akumulacji pierwotnej rolę genealogii elementów, które wejdą w skład kapitalistycznego sposobu produkcji - ponieważ jednak geneza czy też przejście polega w jego ujęciu na wyłanianiu się każdego elementu z osobna, bez strukturalnego powiązania, mówi, że jest to ,jedynie genealogia” (Althusser i Balibar, 1975, 401). W ujęciu Tomby i Mezzadry przeciwnie, chodzi ,aż” o genealogię.
} 
i historię/empirię. Klasa ma charakter istotowy, pozostałe wyznaczniki statusu - charakter przygodny; wyzysk jest istotowy, relacje władzy niemieszczące się pojęciu wyzysku już takie nie są. Na pozór nie sposób się z nie zgodzić z tym twierdzeniem. Jesteśmy przecież przyzwyczajeni do rozróżniania na istotę i przypadłości: wydaje się nam ono koniecznym krokiem wstępnym do prawdziwie naukowej analizy. Zapytajmy jednak: po co wyobrażać sobie kapitalizm trwający bez tych innych, akcydentalnych relacji władzy - kapitalizm, który raczej nie przypomina tego, z którym mamy do czynienia na co dzień? Można oczywiście odpowiedzieć, że chodzi o pożytek poznawczy płynący z abstrakcji - jak poznać x (w tym przypadku - kapitalizm), jeśli nie oddzielając to, co dla niego konstytutywne, od tego, co przygodne?7

Rekonstruując metodę autora Kapitatu, Harvey dochodzi do wniosku, że Marksowska krytyka ekonomii politycznej zakłada skupienie się na produkcji (oczywiście nie jako procesie materialnym, ale na produkcji wartości dodatkowej, która jest procesem społecznym i zarazem stosunkiem klasowym) - to ona jest sercem, rdzeniem, istota całego systemu (Harvey 2015). Oznacza to, że dzieło Marksa pozostaje pęknięte, czy też rozdwojone, na „dwa, jak się wydaje, niewspółmierne systemy pojęciowe” (Harvey 1982, 27) - historię i teorię.

Dlatego rozróżnienie na sposób produkcji (w wąskim sensie, obejmującym tylko abstrakcyjnie rozumianą formę procesu pracy w ramach kapitalistycznego stosunku klasowego) i formację społeczną (szerszą kategorię, oddająca fakt, że nie wszystkie cechy organizacji danego społeczeństwa dają się wyjaśnić przez sposób produkcji) pozostaje dla niego użyteczne, ponieważ pozwala zachować rygorystyczne, precyzyjne ujęcie produkcji jako określonej relacji społecznej (Harvey 1982, 24-27) ${ }^{8}$.

Sam Harvey dostrzega niewystarczalność Marksowskiej ekonomii politycznej - np. dla jego własnych badań nad urbanizacją i jej rola w kryzysach gospodarczych (Harvey 2015). Podkreśla, że zrozumienie przekształceń konsumpcji czy kryzysów gospodarczych nie jest możliwe, jeśli ograniczymy się do samej „czystej” Marksowskiej teorii; niemniej wydaje się sądzić, że marksiści nie mają innego wyjścia, jak tylko postrzegać „historię” i „teorię” jako dwie perspektywy - być może zdolne do połączenia się na poziomie konkretnych badań, ale zasadniczo odrębne i niewspółmierne. Teorii przypada zarazem (jak zwykle w przypadku takich podziałów) status instrumentu uprzywilejowanego, bez którego historia pozostałaby może nie ślepa, ale na pewno nieco krótkowzroczna. Dlatego w swojej najnowszej książce Harvey

\footnotetext{
${ }^{7}$ Althusser powiedziałby, że chodzi tu akceptację empirystycznej koncepcji poznania, gdzie wytwarzanie wiedzy polega na oczyszczaniu istoty z tego, co przygodne i konkretne - wydobywaniu złota prawdy ze szlamu tego, co empiryczne (Althusser i Balibar 1975, 63-64).

${ }^{8} \mathrm{Jak}$ podkreśla Harvey, Marks stosuje pojęcie „sposób produkcji” również w innym, szerszym znaczeniu, gdzie obejmuje ono całokształt produkcji, wymiany i konsumpcji wraz z układami prawnymi, instytucjonalnymi, polityką oraz ideologia; rekonstrukcja tak pojmowanego sposobu produkcji wymagałaby jednak, jak zauważa, mozolnej pracy empirycznej, historycznej. Dlatego autor The Limits to Capital decyduje się pozostać przy węższym, bardziej precyzyjnym rozumieniu sposobu produkcji, dla tego, co się w nim nie mieści, zachowując kategorię formacji społecznej (Harvey 1982, 24-27).
} 
wprowadza rozróżnienie na kapitał (proces akumulacji, ekonomiczna „siła napędowa” kapitalizmu) i kapitalizm - formację społeczna, w której akumulacja kapitału jest główna, ale nie jedyną, działającą siła (Harvey 2014, 7-11). Zakłada również, że można oddzielić opisy obu systemów (tzn. że można analizować kapitał i kapitalizm - a także działające w obrębie kapitalizmu inne systemy władzy, na przykład patriarchat czy rasizm ${ }^{9}$ - osobno, jakby były wzajemnie od siebie niezależnymi bytami). Samo rozróżnienie jest prawdopodobnie użyteczne w wielu kontekstach; moim celem nie jest nawoływanie do jego odrzucenia w ogóle, a tylko zwrócenie uwagi na problematyczne konsekwencje, do których może doprowadzić jego używanie. Opisanie, jak działa „siła napędowa” systemu, w którym żyjemy, jest z pewnością potrzebne; jednak pogląd, że, po pierwsze, można ją oddzielić od samego tego systemu, i, po drugie, że stanowi ona jego istotę, prowadzi do niewrażliwości na złożone interakcje wymogów akumulacji i relacji władzy, które nie są do niej sprowadzalne, ale odgrywaja pewną rolę w jej rzeczywistym funkcjonowaniu w kontekście społecznym. Łatwo wtedy, mimo obstawania przy rozróżnieniu, utożsamić kapitalizm z kapitałem, potraktować kapitalizm tak, jakby był tylko przygodna materializacją kapitału - tego, co istotowe. Fakt, że sam autor tego rozróżnienia płynnie przechodzi w polemicznym kontekście od twierdzenia „musimy odróżnić kapitał i kapitalizm” do twierdzenia „klasa jest ważniejsza”, ukazuje wage problemu.

Twierdzę, za Mezzadrą i Tomba, że w przypadku kapitalizmu posunięcie metodologiczne polegające na odizolowaniu kapitału i kapitalizmu nie zawsze się sprawdza; potrzebne jest przeanalizowanie szczególnej relacji łączącej w obrębie tego drugiego to, co abstrakcyjne z tym, co konkretne. Kapitalizm bywa bowiem postrzegany (i postrzega sam siebie, w swoich ideologicznych autoprezentacjach) jako system uniwersalizujący, albo też jako siła abstrahowania - od konkretności pracy, różnorodności podmiotowości indywidualnej i zbiorowej oraz od lokalnej specyfiki. To, co inne od kapitalistycznej logiki, jest w zetknięciu z nią znoszone, asymilowane lub (w pewnych okolicznościach) niszczone. Ta dialektyka uniwersalności i partykularności nie daje się sprowadzić do statycznego rozróżnienia na kapitał i kapitalizm. Rodzi pytania o naturę kapitalistycznej abstrakcji i o mechanizmy, za pomoca których przekształca ona to, co partykularne i konkretne tak, by jej służyło. Jak właściwie kapitalizm radzi sobie $z$ tym, co napotyka w drodze swojej ekspansji - a także z tym, co rodzi się w jego obrębie, ale nie chce mu się podporządkować?

\footnotetext{
${ }^{9}$ Które zresztą pojmuje w osobliwie ahistoryczny sposób, nie zwracając w ogóle uwagi na ich przekształcenia pod wpływem artykulacji w obrębie kapitalizmu i na funkcję, jaką w tym systemie pełnią.
} 


\title{
Dwie historie kapitalizmu
}

Odpowiedzi na to pytanie próbuje udzielić Dipesh Chakrabarty w Prowincjonalizacji Europy (2000). Obiektem jego krytyki jest, co trzeba podkreślić, nie tyle kapitalizm jako pojęcie marksistowskie, co kapitalizm jako pojęcie wchodzące w skład narracji o nowoczesności/ modernizacji - narracji głównie liberalnej, ale włączającej w swój obręb także pewne elementy marksistowskie (co oznacza, że marksizm z kolei w niektórych swoich wersjach pozostaje częściowo uwikłany w tę narrację). Narracja ta, którą Chakrabarty skrótowo określa jako historyzm, wykorzystuje linearny schemat rozwoju historycznego, powiazany z narracja o wyjątkowości Zachodu/europocentryzmem: nowoczesność pojmowana jest tu jako coś, co pojawiło się najpierw w Europie, a potem „migrowało”, wraz z postępem, do innych części globu.

\begin{abstract}
Historyzm zakładał (..), że czas historyczny jest miarą dystansu kulturowego (przynajmniej w rozwoju instytucjonalnym), który miał istnieć pomiędzy Zachodem i nie-Zachodem (...) historyzm, a nawet nowoczesną europejską koncepcję historii narzucono w XIX wieku nieeuropejskim narodom po to, aby jedni ludzie mogli powiedzieć innym ,jeszcze nie” (Chakrabarty 2011, 9).
\end{abstract}

Dlatego potrzebne jest zakwestionowanie neutralności kategorii takich jak historia, rozwój, uniwersalność, racjonalność czy nowoczesność; projekt „sprowincjonalizowania Europy” ma właśnie to na celu. Nie chodzi tu jednak o ich odrzucenie czy zastapienie kategoriami „niezachodnimi”"10. Jak podkreśla autor Prowincjonalizacji Europy, ten gest krytyczny jest wewnętrzny w stosunku do zachodnich struktur pojęciowych: „myśl europejska jest zarazem niezbędna i nieadekwatna" (Chakrabarty 2011, 21). Niezbędna, ponieważ wyznacza horyzont nowoczesnej teorii i praktyki; nieadekwatna, ponieważ stanowi zarazem technologię władzy kolonialnej. Rozum i cywilizacja w przeszłości, modernizacja czy „rozwój” w czasach bliższych współczesności umożliwiały narzucenie rozwiązań korzystnych dla kolonizatorów, a następnie potęg zachodnich. Podział na to, co nowoczesne i na to, co zacofane, odtwarzał się również, i odtwarza do dzisiaj ${ }^{11}$ wewnątrz samych społeczności postkolonialnych/ peryferyjnych; „,...)

10 Co uparcie, wbrew nie tylko duchowi, ale i literze tekstu, imputuje Chakrabarty'emu Vivek Chibber (Chibber 2013, 14, 18, 22). W pracy Postcolonial Theory and the Specter of Capital Chibber stawia sobie za cel wykazanie i skorygowanie błędów subaltern studies school, m. in. Ranajita Guhy i Dipesha Chakrabarty'ego. O ile trafnie wskazuje na pewne nieszczęśliwe założenia, którymi posługują się subalterniści (na przykład wzięcie przez nich za dobrą monetę liberalnej narracji Europy o samej sobie), o tyle fakt, że sam posługuje się przy tym mało subtelnym, niedialektycznym pojęciem uniwersalności (uniwersalność kapitału ma jego zdaniem po prostu unieważniać partykularne różnice), wydaje się bardzo obniżać wartość jego krytyki. Najgorsze z całej książki są właśnie rozdziały poświęcone Chakrabarty’emu, które czyta się nie jak krytykę, ale jak pełen frustracji atak na „poststrukturalistyczny bełkot”.

11 Mechanizm internalizacji zachodnich kategorii burżuazyjnych przez elity krajów peryferyjnych i funkcjonowanie „nowoczesności” jako mechanizmu dyscyplinarnego można obserwować tak w Indiach lat 
elity ruchu narodowego często same próbowały stosować wobec własnych klas podrzędnych etapową wizję historii (i wciąż to robią, jeśli pozwalają im na to struktury polityczne), na której opieraja się europejskie idee nowoczesności politycznej” (Chakrabarty 2011, 11). Dekonstrukcja pojęć postępu, modernizacji, czy kapitału z jego abstrakcyjną strukturą ma na celu zakończenie ideologicznej oscylacji między dwoma biegunami zestawu wzajemnie się wzmacniających dychotomii: Zachód/Wschód, rozum/tradycja, europocentryczny racjonalizm/orientalistyczna fascynacja ,innymi kulturami”.

Nie chodzi więc o negowanie tego, że kapitalistyczna abstrakcja jest realną siłą, ale o pokazanie, że ta siła bierze się konsekwentnego asymilowania tego, co inne - redefiniowane jako „zacofane” czy archaiczne. Linearny schemat rozwoju wykorzystywany w narracjach o modernizacji nie jest po prostu fikcja - obowiązuje, ponieważ stanowi główny mechanizm narzucania władzy kapitału; ale jako taki nie jest neutralny politycznie i należy go sproblematyzować ${ }^{12}$. Można mieć wątpliwości, czy dekonstrukcyjne narzędzia, które wykorzystuje Chakrabarty, są rzeczywiście najlepsze dla tego celu. Niemniej jego propozycja pozwala (jak zobaczymy) dostrzec w marksistowskich ujęciach kapitalizmu nowe aspekty.

Krytyka centralnego dla historyzmu pojęcia uniwersalnej historii nie będzie więc polegać na zastapieniu jej mnogością historii partykularnych, ale na pokazaniu, że pozostaje ona w koniecznym, konstytutywnym stosunku do tego, co partykularne ${ }^{13}$. Temu służy wprowadzony w Prowincjonalizacii Europy podział na Historię 1 i Historię 2. Pierwsza z nich obejmuje te elementy dynamicznej struktury kapitalizmu, które zostały przez nią samą ustanowione:

\begin{abstract}
(...) Marks nazywa historię przesłanką kapitału przez [sam kapitał] stworzona. Wolna praca jest tutaj zarówno warunkiem produkcji kapitalistycznej, jak i jej „stałym wynikiem". Jest to uniwersalna i niezbędna historia, którą wiążemy z kapitałem. (...) nazwijmy tę historię - przeszłość, stworzoną przez sam kapitał jako swój własny warunek - Historią 1 (Chakrabarty 2011, 80).
\end{abstract}

dwudziestych-siedemdziesiątych, jak we współczesnej Polsce. Trzeba tu jednak wspomnieć, że pozycja teoretyków postkolonialnych (obok Chakrabarty'ego wymieniani są Gayatri Chakravorty Spivak i Homi Bhabha) w ramach hierarchii centrum/peryferie jest dość dwuznaczna. Będąc przedstawicielami kosmopolitycznych elit, z ochota zajmują oni w obrębie zachodniej akademii miejsce „podmiotu z Trzeciego Świata/niezachodniego innego" (Dirlik 1994).

${ }^{12}$ Można by powiedzieć (dziękuję Michałowi Pospiszylowi za tę inspirację), że obowiązuje on trochę tak, jak nowoczesna puryfikacja w ujęciu Bruno Latoura (Latour 2011). Nowoczesność, przekonana, że jej specyfika jest oddzielanie porządków rzeczywistości, które w społeczeństwach przednowoczesnych były zmieszane, w istocie mnoży hybrydy na skalę wcześniej niespotykaną - co jest możliwe właśnie dzięki owemu przekonaniu, które jest czymś więcej niż ,ideologicznym złudzeniem”. Jest realną siła, powodującą realne skutki - tyle, że po bliższym przyjrzeniu się widzimy, iż są to skutki dokładnie odwrotne niż te, które wytwarza ona w swoim mniemaniu.

${ }^{13}$ To w gruncie rzeczy dość „Heglowski” ruch - użytek, jaki czyni Chakrabarty z dekonstrukcji, pokazuje, że ma ona (przynajmniej potencjalnie) wiele wspólnego z dialektyka. 
Historia 2 to z kolei te elementy, które istniały niezależnie od niej (przy czym nie precyzujemy, czy chodzi o istnienie wcześniejsze w sensie czasowym, czy o inaczej pojmowaną niezależność) i zostały z nią zintegrowane:

\begin{abstract}
Marks przeciwstawia takiej historii inny rodzaj przeszłości, który nazwiemy Historią 2. Elementy Historii 2 to także „przesłanki” kapitału, ponieważ „kapitał zastaje je jako przesłanki”, lecz - i tutaj następuje najbardziej kluczowe rozróżnienie - „nie jako przesłanki, które sam tworzy, nie jako formy własnego procesu życiowego" (Chakrabarty 2011, 80).
\end{abstract}

Przykłady Historii 2 to pieniądz i towar (Chakrabarty 2011, 81); badacz stosuje potem to rozróżnienie do opisu rzeczywistości kolonialnej - widzimy jednak, że podstawowa różnica dotyczy tego, czy dana przesłanka została ustanowiona i zarazem stworzona przez kapitał (jak wolna praca), czy też kapitał napotkał ją i zintegrował ze sobą (jak pieniądz). Nie chodzi więc po prostu o to, że kapitalizm napotyka to, co niekapitalistyczne (czy przedkapitalistyczne); ani o to, że Zachód napotyka to, co niezachodnie. Oba te procesy sa przykładami ogólniejszej, bardziej abstrakcyjnej dynamiki: kapitalizm w trakcie swojego stawania się (genezy) ustanawia swoje przesłanki (wolną prace i wolny kapitał), ale także napotyka to, co wobec niego zewnętrzne, i próbuje to ze sobą zintegrować.

Kwestia owego utrzymywania się w obrębie kapitalizmu jako formacji społecznej elementów „niekapitalistycznych” (i szerzej, różnorodności stosunków produkcji, które jest on w stanie zasymilować) pokrywa się z problematyką subsumcji mieszanej i formalnej ${ }^{14}$. Ta druga, częściej opisywana, dotyczy podporządkowania poprzez nawiązanie stosunku pracy najemnej, bez ingerencji w postać produkcji. Pierwsza, rzadziej dostrzegana ${ }^{15}$, oznacza podporządkowanie za pomocą nie przekształcenia postaci produkcji czy stosunku pracy najemnej (nie zachodzi tu wyzysk pracy; wartość dodatkowa jest zawłaszczana w formie procentu od zainwestowanego kapitału), lecz stosunku handlowego bądź długu. Jej przykładem są kapitał handlowy czy kapitał lichwiarski, jak również outsourcing (np.

\footnotetext{
${ }^{14}$ Subsumcję można, jak podaje Krystian Szadkowski, rozpatrywać na czterech poziomach: a) empirycznym - sektorowym, b) empirycznym - dotyczacym historycznie istniejących formacji gospodarczych, c) empirycznym - globalnym oraz d) ontologicznym (Szadkowski 2015). Odwołuję się do tego podziału poniżej. Ponieważ jednak zakłada on przede wszystkim odróżnienie poziomu ontologicznego i empirycznego, które staram się zakwestionować, w tym miejscu nie jest dla mnie przydatny.

${ }^{15}$ Subsumcja formalna i realna są opisywane częściej, bywają też interpretowane na sposób stadialny, zgodnie z modelem linearnym (po etapie subsumcji formalnej musi nastapić etap subsumcji realnej). Jest to, jak podkreśla Szadkowski (2015) błąd: subsumcja formalna jest warunkiem koniecznym subsumcji realnej (subsumcja formalna w danym sektorze stwarza warunki dla subsumcji realnej), nie oznacza to jednak, by ta druga musiała następować po pierwszej na poziomach b, c i d (jak sugeruje model linearny. O ile subsumcja realna stawowi formę pełniejszą i „swoiście kapitalistyczną", umożliwiającą lepszą akumulację w danym sektorze, o tyle tendencja spadkowa stopy zysku sprawia, że kapitał niejednokrotnie zmuszony jest przenieść się z sektora podporządkowanego realnie, w którym spada ogólna stopa zysków, do sektora, w którym praca podporządkowana jest tylko formalnie.
} 
działalność agencji pośrednictwa pracy). Umożliwia ona poddanie władzy kapitału tych form produkcji, które sa zorganizowane na sposób niekapitalistyczny, bez konieczności ingerencji w postać produkcji czy nawiązywania stosunku pracy najemnej - na przykład pracy niewolniczej. Ta forma subsumcji, którą może się nam wydawać czymś marginalnym, jest w istocie ważniejsza dla funkcjonowania „normalnego” historycznego kapitalizmu, niż sugerowałby model linearny (Szadkowski 2015).

Sytuacje, w których kapitał podporządkowuje sobie produkcję, nie ingerując w jej materialna postać (subsumcja formalna) albo w których czyni to, nie narzucając produkcji nawet formy pracy najemnej, ale za pośrednictwem stosunków handlowych lub długu (subsumcja mieszana), to przykłady paradoksalnego istnienia Historii 2 wewnattrz kapitalistycznej struktury. Jak twierdzą Tomba i Mezzadra (potwierdzając tezę Chakrabarty'ego, ale jednocześnie pokazując, że da się ją sformułować w języku marksistowskim), subsumcja formalna nie jest wcale początkowym stadium kapitalizmu, po którym ma nastapić przekształcenie produkcji na sposób kapitalistyczny - subsumcja realna. W „rzeczywiście istniejącym kapitalizmie” wziętym jako całość (poziom globalny (c) subsumcji) mamy zwykle do czynienia $z$ istnieniem wielu form hybrydycznych, pośrednich między subsumcją formalna a realna; różne sektory systemu są pod tym względem zróżnicowane. Podobnie względnej wartości dodatkowej towarzyszy bezwzględna wartość dodatkowa (Tomba 2012, 169; Tomba 2011). „Rozważany w swym długim historycznym trwaniu, jak również w swym wymiarze systemu-świata kapitalizm cechuje się strukturalną współobecnością subsumcji formalnej i realnej, bezwzględnej i względnej wartości dodatkowej” (Mezzadra 2014, 73). Nie tylko ruch kapitału pomiędzy poszczególnymi sektorami przeczy modelowi linearnemu, ale i obecność subsumcji mieszanej oraz idealnej (podporządkowania kapitałowi na sposób ideologiczny, dyskursywny) komplikuje obraz kapitalizmu.

Stopień, w jakim kapitał przyswaja bardzo różnorodne formy produkcji i organizacji społecznej, można zilustrować, przytaczając zrekonstruowane przez Erica R. Wolfa w pracy Europa $i$ ludy bez historii przekształcenia, jakim podlegały niezachodnie społeczeństwa w toku stopniowego podporządkowywania zachodniemu protokapitalizmowi. Niekapitalistyczne sposoby produkcji i formacje społeczne były sukcesywnie „przekładane” na język kapitału (będącego w fazie subsumcji formalnej) najczęściej na drodze specjalizacji w dostarczaniu konkretnego towaru, na który zgłaszało zapotrzebowanie gospodarcze centrum. Wśród przykładów autor wymienia między innymi popularność w Afryce w wiekach XVI-XIX modelu militarystycznego, scentralizowanego państwa zawdzięczającego swoją siłę gospodarcza pozyskiwaniu niewolników, sprzedawanych następnie Europejczykom (Aszanti, Ojo, Dahomej) (Wolf 2009, 227-228; 238). Kolejny przypadek to związane ze „specjalizacja” $\mathrm{w}$ handlu futrami przekształcenia w strukturze społecznej niektórych plemion Indian Północnoamerykańskich (między innymi Huronów i Irokezów). Polegały one, w skrócie, na 
nasileniu się tendencji „,indywidualistycznych”: miarą społecznego sukcesu stały się osiągnięcia ekonomiczne poszczególnych jednostek, co spowodowało wzrost rozwarstwienia i pogorszenie się statusu kobiet (ponieważ to mężczyźni zmonopolizowali handel futrami) (Wolf 2009, 191, 205-207, 221). Jak podkreśla Wolf, społeczeństwa, które później antropologowie będa badać jako „pierwotne”, były w istocie produktem kapitalistycznej ekspansji. „Większość społeczeństw badanych przez antropologów stanowi wytwór ekspansji Europejczyków, a nie nietknięty osad minionych stadiów ewolucyjnych" (Wolf 2009, 87).

Czy te państwa i plemiona były „kapitalistyczne”? W wąskim sensie oczywiście nie w przekształceniach, jakim podlegały, nie mogło być mowy o subsumcji realnej ani formalnej; ale jednocześnie rozwijający się kapitalizm zarówno czerpał korzyści z ich „handlowej specjalizacji”, jak i wpływał na wszystkie ich wymiary - nie tylko produkcję w wąskim sensie, ale i kształt struktur pokrewieństwa czy relacje między płciami. Zostały one - co ważne z punktu widzenia perspektywy Chakrabarty'ego - podporządkowane rodzącemu się systemowi kapitalistycznemu właśnie jako niezachodnie i nieburżuazyjne (a nie „pomimo” faktu, że odbiegały w swej strukturze od modelu zachodniego). Sytuacja taka, stanowiąca przypadek subsumcji mieszanej, była w perspektywie globalnej niezwykle funkcjonalna dla kapitalistycznej akumulacji.

Przekład tego, co niekapitalistyczne, na logikę kapitału, jest więc złożonym procesem zakładającym różnorodność praktyk - od prostej asymilacji po podporządkowywanie niekapitalistycznych sposobów produkcji w ich odmienności. Chakrabarty stawia w tym kontekście tezę o nieredukowalnym rozziewie i zarazem nierozstrzygalności między Historią 1 i Historia 2. Dla wielu konkretnych formacji trudno rozróżnić, które ich elementy pozostaja konstytutywne dla kapitalizmu jako pojęcia, a które są „tylko” historyczne i przygodne, stanowią przeżytek czy też pozostałość po przedkapitalistycznej przeszłości (Chakrabarty 2011, 88). Kapitalizm w tym ujęciu jest zatem strukturą naznaczoną wewnętrzną luka/odroczeniem, sprawiającym, że nigdy nie jest w pełni tożsamy ze sobą (jak widzimy, Chakrabarty polega tu na klasycznym geście dekonstrukcyjnym). Owo odroczenie, określane przez niego jako różnica historyczna, odpowiedzialne jest za napięcie między istnieniem kapitału a jego powstawaniem czy też stawaniem się. Pozostajemy nieustannie w obrębie jednej struktury („kapitalizmu”); ale żeby mogła ona istnieć, czyli odtwarzać się, potrzebny jest ten skomplikowany proces nigdy niedopełnionego, pozostawiającego po sobie niemożliwą do zasymilowania resztkę przekładu (Chakrabarty 2011, 79). Dlatego kapitalistyczna struktura zawsze pozostaje niekompletna.

(...) to, co „przedkapitalistyczne”, może istnieć jedynie w obrębie czasowego horyzontu kapitału i jednocześnie zaburzać ciagłość tego czasu przez sugerowanie istnienia innego czasu, nie mierzonego tym samym świeckim, jednolitym kalendarzem (dlatego właśnie prekapitał nie jest chronologicznie wcześniejszy od kapitału - nie można umieścić go na tej samej ciagłej skali czasu) (Chakrabarty 2011, 119). 
Fakt, że kapitalizm składa się z Historii 1 i Historii 2, połączonych paradoksalną relację napięcia i nierozstrzygalności, sprawia, że historiografia staje przed koniecznością przekładu. Kapitalizm przekłada Historię 2 na Historię 1; z kolei teoretyk może przełożyć konkretne formacje, które analizuje, na Historię 2 (Chakrabarty 2011, 90). Ten przekład nie jest tylko czymś, co dotyczy peryferyjnego czy kolonialnego kapitalizmu. Europa Zachodnia też ma swoja Historię 2. Historia klasy robotniczej, na przykład E. P. Thompsona (1966), czy (dla Polski) Niny Assorodobraj (1946), to kolejne oblicze Historii 2, pojmowanej jako coś wewnętrznego dla Historii 1, ale zarazem rozsadzającego ją od środka. Różnica historyczna pozostaje więc koniecznym momentem ruchu tego, co uniwersalne ${ }^{16}$.

Chakrabarty wydaje się sądzić (w dobrym dekonstrukcyjnym duchu), że to w tym rozziewie i niedomknięciu struktury należy szukać możliwości oporu wobec kapitalizmu. Jak jednak słusznie zauważa Chibber, fakt wewnętrznej niespójności struktury nie mówi nam nic o możliwości jej demontażu (Chibber 2013, 229). Przykłady Wolfa, jak również fakt, że liczne przywoływane przez samego Chakrabarty'ego elementy Historii 2, takie jak pieniądz czy tradycyjne struktury pokrewieństwa, wręcz ułatwiają akumulację kapitalistyczna, tylko potwierdzaja słabość tej tezy. Jednak Chibber, stawiając tezę, że tylko Historia 1 (czyli abstrakcyjna struktura odpowiedzialna za akumulację kapitalistyczna) jest źródłem oporu (zgodnie z podzielanym przez wielu marksistów poglądem, że tylko uprzednia proletaryzacja może być podstawą „prawdziwej” walki”": robotnik może stawiać opór dlatego, że jest robotnikiem), również nie pozwala na postawienie problemu w bardziej satysfakcjonujący sposób. Zakłada bowiem, że problem relacji kapitału do kapitalizmu (czy też logiki do historii/empirii) zwyczajnie nie istnieje albo też znajduje się „poniżej” poziomu teoretycznego, na którym operuje marksizm. Kapitalizm, jego zdaniem, po prostu współistnieje z niekapitalistycznymi czy też nieburżuazyjnymi formami podmiotowości i władzy społecznej ${ }^{17}$ - to, w jaki sposób współistnieje, to kwestia zaledwie historyczna czy empiryczna. Narracja historiograficzna o koniecznym powiązaniu kapitalistycznych stosunków produkcji z burżuazyjnymi formami polityczności i upodmiotowienia jest z kolei po prostu fikcją. Choć jest to rozwiązanie zarazem proste i zgodne ze zdrowym rozsądkiem, sądzę, że bardziej skomplikowana odpowiedź jest w tym przypadku lepsza niż ta prostsza. Jest tak, ponieważ możliwość opisania, dla konkretnych przypadków, na czym polega interakcja kapitalistycznej organizacji procesu pracy, stosunków produkcji i nie- bądź przedkapitalistycznych sposobów produkcji czy form uspołecznienia, oznacza również możliwość zrozumienia, dlaczego opór

\footnotetext{
16 Przesuwam tu nieco akcenty; Chakrabarty, który kładzie nacisk raczej na zerwanie, jakie stanowi różnica historyczna oraz na niemożność domknięcia struktury, prawdopodobnie nie ująłby tego w ten sposób. Por. też alternatywne wobec dekonstrukcyjnego, wywodzące się z ontologii spinozjańskiej ujęcie uniwersalności nowożytnych walk klasowych w tekście Michała Pospiszyla (Pospiszyl 2013).

${ }^{17}$ Chibber nie rozróżnia między kapitałem a kapitalizmem; nie wydaje się też uważać, by relacja między nimi zasługiwała na problematyzację (Chibber 2013, 26, 224-225).
} 
przybiera w danych przypadkach takie a nie inne formy. Robotnik stawia opór dlatego, że jest robotnikiem; ale również dlatego, że nigdy nie jest tylko siła roboczą. Jeśli uznamy, że marksizm nie jest w stanie opisać tych konkretnych uwarunkowań, będziemy zmuszeni uciekać się (jak czyni to Chibber) do mętnych, metafizycznych (czy może: niedialektycznych) kategorii takich jak „uniwersalne człowieczeństwo”, w obronie którego rzekomo toczą się wszystkie antykapitalistyczne walki.

Z kolei realność kapitalistycznych stosunków produkcji i „fikcja” ich ideologicznej legitymizacji nie dają się od siebie oddzielić tak łatwo, jak chciałby autor Postcolonial Theory and the Specter of Capital. Najlepsza tego ilustracja jest fetyszyzm towarowy: mechanizm, który wytwarza efekty jednocześnie ideologiczne i obiektywne, tzn. działające w obrębie praktyk, a nie dyskursów. Rozróżnianie między tymi obiektywnymi efektami a efektami ideologicznymi wytwarzanymi w sferze nadbudowy jest problematyczne; być może dobrym rozwiązaniem byłoby uznanie, że oba typy efektów na ogół współgrają (do tego stopnia, że często nie można ich odróżnić), składając się razem na kapitalistyczną fantasmagorię - zarazem realną i widmowa, dyskursywną i materialną (Tomba 2013, 110). Ideologia (na przykład progresywizm połączony $\mathrm{z}$ europocentryzmem), przejawiająca się $\mathrm{w}$ dyskursie, ale $\mathrm{i} \mathrm{w}$ materialnych praktykach, jest realna, obiektywna i skuteczna; doświadczenie kolonialne stanowi tu najbardziej uderzający przykład. Dlatego nie możemy po prostu uznać narracji na temat kapitalizmu za fikcję i przeciwstawić jej prawdy.

Chibber i Chakrabarty zgodziliby się prawdopodobnie co do tezy, że zagadnienia przekładu niekapitalistycznych „światów życia” na logikę kapitału nie da się opisać w języku marksistowskim; gdyby tak było, marksizm i teoria postkolonialna musiałyby pozostać wzajemnie niewspółmierne. Nie sądzę jednak, wbrew temu, co twierdzi Gayatri Chakravorty Spivak (Spivak 2011, 181), by podtrzymywanie niespójności między marksizmem i dekonstrukcją miało nam przynieść jakieś szczególne korzyści poznawcze. Mezzadra i Tomba wskazuja jednak na możliwość innego ujęcia, pozwalającego na opis w języku marksistowskim skomplikowanych relacji między uniwersalistyczną dynamiką kapitału oraz konkretnymi, lokalnymi czasowościami, które usiłuje ona ze sobą zintegrować (a zarazem między logika i historia).

\section{Praca synchronizacji}

Jednym z głównych odniesień Chakrabarty’ego w Prowincjonalizacji Europy jest Walter Benjamin z O pojeciu historii, przeciwstawiajacy homogeniczny, pusty czas linearnej historii czasowi mesjanicznemu/politycznemu, przeszłości wypełnionej teraźniejszościa, czasowi „rozsadzania kontinuum historii" (Benjamin 1996). Patronuje on również Tombie w Marx's Temporalities. Praca ta, przywołująca Chakrabarty'ego (choć tylko na marginesie) i również poświęcona 
problemowi różnorodności i niewspółmierności struktur czasowych kapitalizmu, zarysowuje jednakże obraz bardziej złożony niż ten z Prowincjonalizacji Europy.

Tomba przyjmuje - podobnie jak Althusser - że czasowość jest czymś swoistym dla struktury (por. Althusser i Balibar 1975, 149). Nie zakłada jednak, że czasowości mogą być atrybutem wyłącznie sposobów produkcji i względnie autonomicznych praktyk; dwie praktyki (na przykład gospodarka i polityka) moga dzielić jedną czasowość, czy raczej zintegrować nawzajem swoje czasowości; z kolei w obrębie jednej praktyki może dojść (i ta sytuacja jest głównym przedmiotem jego zainteresowania) do pojawienia się wielu czasowości. Zwraca również szczególną uwagę na relacje, które mogą się nawiązać między tymi czasami: synchronizację czy też wzajemny przekład.

Kapital jest obojętny wobec horyzontów czasowych i struktur społecznych, dlatego może je sobie podporządkowywać; nie odbywa się to jednak po prostu za sprawą unicestwienia tego, co specyficzne, ani za sprawa, jak chciałby Chibber, przekształcenia tylko tego, co gospodarcze (Chibber 2013, 241-242). Poszczególne podstruktury czy też praktyki nie są od siebie niezależne (a relacje między nimi nigdy nie są możliwe do określenia z góry). Postać tych relacji jest efektem przekładu niewspółmiernych czasowości na czasowość kapitalistyczna, co obejmuje zwykle gospodarkę, kulturę oraz społeczne relacje władzy. Historia powszechna, którą próbował zdekonstruować Chakrabarty, nie jest więc fikcją, ale jak najbardziej rzeczywistym wytworem kapitalistycznej dynamiki. Uniwersalność kapitału po bliższym zbadaniu nie jest jednak czymś swoistym, dającym się oddzielić od partykularności urządzeń kapitalizmu. Wytwarza się raczej w obrębie kapitalizmu, jako jego wewnętrzna cecha, w oparciu o relacje między wielością konkretnych czasów. Uniwersalność kapitału stanowi wynik synchronizacji - integracji różnych czasowości, które wchodzą w skład systemu.

Ów przekład wielości czasów na jeden czas kapitału nigdy nie jest jednak kompletny. Jednolita czasowość (na przykład ta, która Althusser i Balibar przypisuja produkcji w ramach kapitalistycznego sposobu produkcji) po bliższej inspekcji ujawnia resztki odmiennych, niezintegrowanych czasów, niespójności i zakłócenia. Polityczne i teoretyczne wyzwanie stojące przed materializmem historycznym polega więc na rekonstrukcji, w obrębie danej dziejowej konfiguracji, wielości asynchronicznych warstw czasowych poddanych procesowi synchronizacji (Tomba 2013, xiv).

Nie chodzi tu wyłącznie o pozostałości z epok wcześniejszych - jak wiemy dzięki Benjaminowi, rewolucyjna teraźniejszość często kryje w sobie fragmenty przyszłości, niewczesne i często źle interpretowane, niosące ze sobą utopijną obietnicę domagająca się wypełnienia od przyszłych pokoleń. Jak pokazuje Tomba, świetnie unaocznia to czasowa kompozycja rewolucji francuskiej, obejmująca, poza burżuazyjnym głównym nurtem, kontrczasowości: walka niewolników na Haiti o wyzwolenie i polityczne samostanowienie, ludowe postulaty stawiające $\mathrm{w}$ centrum kwestię cen $\mathrm{i}$ własności czy postulaty 
równouprawnienia kobiet. Polityka to przekład mnogości czasów historycznych: odzyskanie przeszłych walk o emancypację oznacza możliwość postrzegania obecnych walk w nowym świetle, otwarcie nowego horyzontu politycznego (Libera Università Metropolitana 2014, 24). Konfiguracja ta nie tylko opiera się podporządkowaniu jednemu pojęciu, takiemu jak rewolucja burżuazyjna, ale i retrospektywnemu wpisywaniu wszystkich tych walk w jedną, czytelną dzisiaj, linię konsekwentnej demokratyzacji (co proponuje Chibber, twierdząc, że rewolucja francuska to tylko jeden z przykładów dynamiki, która jest identyczna dla wszystkich nowożytnych rewolucji na całym globie: klasy podporządkowane walczą o demokratyzację, a elity dążą do nieznacznego przegrupowania sił). Ten drugi opis podstawia bowiem tylko jedną hegemoniczną czasowość (demokratyzacja, której nośnikiem są „klasy podporządkowane”) za inną (demokratyzacja burżuazyjna); usuwa przy tym napięcie stwarzane przez obecność różnych czasowości w obrębie jednego wydarzenia historycznego. „Należy uchwycić historyczne uwarstwienie nowoczesności, wytworzone przez walki klasy podporządkowanej, nie zaś fałszywy obraz nowoczesności jako niezróżnicowanej, gładkiej powierzchni” (Tomba 2013, 19; por. Althusser i Balibar 1975, 150-151). Czas kapitału jest abstrakcyjny, ale tylko dopóty, dopóki nie napotka historycznych kontrczasowości walki klas; owocem tego spotkania jest przygodny czas historyczny. Stąd użyteczność przywoływanej nieustannie przez Tombę metafory geologicznej, każącej pojmować czasowość konkretnej konfiguracji historycznej jako zestaw warstw, nakładających się na siebie, a nie następujących po sobie. Zakłada to przede wszystkim możliwość zaburzenia linearnego porządku - sfałdowania, wskutek którego teraźniejszość zawiera w sobie fragmenty przeszłości i przyszłości: „Materialista historyczny traktuje epoki historyczne jak epoki geologiczne, zapewnia widzialność poszczególnych warstw" (Tomba 2013, 175).

Dlatego autor Marx's Temporalities proponuje, by stosunek kapitalizmu i przedkapitalistycznych sposobów produkcji interpretować jako synchroniczną różnicę w obrębie samego kapitalizmu (Tomba 2013, 68). Unikamy w ten sposób historystycznej wizji, zgodnie z którą kapitalizm miałby wyewoluować z przedkapitalistycznych sposobów produkcji. Przyjmujemy perspektywę synchroniczną, tzn. pozostajemy w horyzoncie kapitalizmu - ale dostrzegamy zarazem, że ten horyzont jest zawsze poprzecinany innymi horyzontami. „W anatomii człowieka znajdujemy klucz do anatomii małpy, w tym sensie, że synchroniczne istnienie człowieka i małpy staje się podstawą diachronicznego wyjaśnienia, które odsłania przed nami nie ewolucję, ale raczej różnicę miedzy człowiekiem i małpą” (Tomba 2013, 68). Intuicja znajdująca się u podstaw tego dość kontrintuicyjnego twierdzenia jest następująca: nie interesuje nas to, co „przed” - bo to, co było przed w sensie linearnym, nie wyjaśnia tego, co jest teraz. Niemniej różnica czasowa jest istotna - tylko że jest ona obecna wewnątrz „teraz”. Jakie może mieć to konsekwencje dla polityki? Przede wszystkim umożliwia dostrzeżenie, że w tym, co na pozór anachroniczne, moga tkwić zalążki przyszłości; z kolei 
„przedkapitalistyczne” formy społeczne i polityczne moga się świetnie przystosować do kapitalizmu.

Jak podkreśla Tomba, takie ujęcie czasowości nie kojarzy nam się ze standardowymi interpretacjami dzieła Marksa - jest to jednak skutek wybiórczej lektury, nieuwzględniającej ewolucji poglądów autora Kapitału. Marks posługiwał się historiograficznym modelem przyczynowości linearnej, zakładającym połączenie progresywizmu z europocentryzmem, tylko we wcześniejszych fazach twórczości. Odchodził też stopniowo od modelu, w którym najbardziej zaawansowane gospodarki mają stanowić awangardę - lokomotywę ciagnąca za soba pozostałe wagony (Tomba 2013, 66), na rzecz bardziej złożonego modelu, w którym kapitalistyczny sposób produkcji to kombinacja rozmaitych czasowości, podlegających przekładowi, ale i opierających się mu.

Powyższa interpretacja ma też konsekwencje dla sposobu, w jaki sam Tomba odczytuje dzieło Marksa, ze szczególnym uwzględnieniem zagadnienia relacji między logiką a historia. Jak podkreśla, pierwsze sześć rozdziałów Kapitału to nie tylko łańcuch dedukcyjny, któremu towarzyszą konkretne przykłady (których można by się bez szkody dla wywodu pozbyć): „tak zwane historyczne partie Kapitału nie są ani dodatkami, ani tylko przykładami” (Tomba 2013, 117). Skupienie się tylko na logice oznaczałoby uleganie fetyszyzmowi, każącemu nam wierzyć, że to, co materialne, jest bezpośrednio ujmowalne i niezależne do tego, co abstrakcyjne. Dlatego na przykład Marks wychodzi nie od pojęcia towaru, ale od towaru w jego konkretności, co pozwala dojść do wniosku, że towar to konkretna forma społeczna wytworu pracy. Analiza fetyszyzmu towarowego umożliwia dostrzeżenie, iż forma jest tym, co konkretnie społeczne (a nie kategorią, która narzucamy na rzeczywistość). Innymi słowy: abstrakcja jest tym, czym jest, dzięki konkretowi; ale konkret z kolei istnieje tylko jako nośnik abstrakcji. Dotyczy to i poziomu (fetyszyzm w kapitalizmie, forma wartości), i metapoziomu (teoria Marksa).

W dziele Marksa, jak przekonuje Tomba, nie da się oddzielić tego, co formalne, od tego, co konkretne/historyczne. Te dwa wymiary pozostają ze sobą w pełnej napięcia relacji. Abstrakcyjne prawa rozwoju kapitału konkretyzują się tylko napotykając różne historyczne czasowości; usiłują je zsynchronizować, ale nigdy nie udaje im się to w pełni. Kategorie tendencji i kontrtendencji sa według Tomby wynikiem owego zderzenia kapitalistycznego dążenia do synchronizacji z oporem tego, co się jej nie do końca poddaje. Rywalizacja między poszczególnymi kapitałami, istnienie różnych form pośrednich między subsumcją formalna a realną każą postrzegać tendencję całego systemu jako złożoną i nielinearną poprzerywaną kontrtendencjami. Z analogiczną złożonością i heterogenicznością mamy do czynienia w samych tekstach Marksa. Raporty inspektorów fabrycznych w Kapitale czy opis walki o skrócenie dnia roboczego nie są tylko empirycznym „mięsem”, którym należy obudować teoretyczny szkielet, ale wprowadzają weń wymiar kontrczasowości, rozbijający i komplikujący 
linearny porządek: „Raporty o walkach robotniczych nie stanowią dla Marksa tylko dziennikarskich sensacji, które można przytoczyć jako ilustrację, ale punkty kondensacji, w których cały wywód teoretyczny podlega koncentracji i eksploduje" (Tomba 158). Podobnie interpretuje Tomba rolę, jaką w wywodzie Marksa odgrywa angielski kapitalizm oraz angielskie walki robotnicze. Latwo uznać je za model tego, jak działa kapitalizm jako abstrakcja: empiryczny przykład angielski byłby, ponieważ zawiera stosunkowo najmniej niekapitalistycznych „domieszek” (widzimy w nim, w największym stopniu spośród wszystkich dostępnych społeczeństw, przede wszystkim działanie sił kapitału), uprzywilejowaną ilustracją kapitalizmu jako pojęcia. Nie jest to jednak jedyna możliwa interpretacja. Zdaniem Tomby Marks nie skupia się na Anglii dlatego, że stanowi ona ucieleśnienie uniwersalnego, abstrakcyjnego kapitalizmu, ale dlatego, że jej przykład pozwala na ukazanie adekwatnych do ówczesnych warunków strategii walki; fragmenty oświęcona Anglii to „performatywna historiografia" (Tomba 2013, 162).

\section{Ciągła akumulacja pierwotna}

Powróćmy do pojęcia akumulacji pierwotnej. Możemy teraz wykazać, w jakim sensie umożliwia ono zniesienie podziału na metropolię i kolonie oraz na logikę i historię ${ }^{18}$. Akumulacja pierwotna jest dokładnie tym momentem, w którym kapitalistyczna struktura ustanawia siebie - wciąż na nowo - za pomocą zderzenia logiki kapitału z tym, co inne/niekapitalistyczne i następującego potem przekładu. Zarówno Mezzadra, jak i Harvey zgadzają się co do tego, że wytwarzanie „stanu wyjątkowego” jako strategia akumulacji kapitału nie należy do przeszłości. Jak ujmuje to Harvey, akumulacja przez wywłaszczenie - „utrzymywanie się i upowszechnianie praktyk akumulacji, które Marks uważał za "prymitywne« albo "pierwotne«", to jeden z głównych mechanizmów działania neoliberalnego kapitalizmu. Należy do nich „utowarowienie i prywatyzacja ziemi, połączone z przymusowym rugowanie z niej ludności chłopskiej (...), przekształcanie rozmaitych form praw własność (wspólnej, kolektywnej, państwowej) w prawa wyłącznej własności prywatnej” (Harvey 2008, 213), a także narzucanie pracy najemnej i zawłaszczanie zasobów naturalnych (Harvey 2008, 214; Harvey 2010, s. 289313).

Widzimy zatem, że nie można w prosty sposób oddzielić kapitalistycznej normy od wyjątku, subsumcji formalnej od realnej, sytuacji, w której obowiązuje „zwyczajny bieg rzeczy” od takiej, „w której produkcja kapitalistyczna dopiero powstaje” (Marks 1968, 877). Jak stwierdza Tomba, to akumulacja pierwotna narzuca rytm społecznie niezbędnego czasu pracy

\footnotetext{
18 A także na dynamikę i diachronię (por. Althusser i Balibar, 1975, 431).
} 
na skalę globalną i dokonuje różnicowania oraz synchronizacji odmiennych czasowości (Tomba 2013, 169). Ponieważ struktura jest dynamiczna, musi się reprodukować (Goldmann 1978). Kapitalistyczna synchronizacja napotyka na opór kontrczasowości, więc moment genezy musi powracać: „owo spięcie między abstrakcją a konkretem musi się powtarzać każdego dnia” (Mezzadra 2014, 45).

Akumulacja pierwotna to mechanizm, za pomocą którego logika może zaistnieć jako historia. Rozdział 24. Kapitału dostarcza nam opisu „warunków, w których (...) zespół »rzeczywistych abstrakcji« »ucieleśnia się« w historii, zyskujących status rzeczywistych sił” (Mezzadra 2014, 45) Kapitalizm faktycznie jest ruchem uniwersalizacji; ale dokonuje się ona za pośrednictwem nie tyle wyeliminowania, co dostosowania i przekształcenia - nigdy w pełni udanego - tego, co się temu ruchowi wymyka. Sam opis działania kapitału nie wystarcza więc, by zyskać pełny obraz.

\footnotetext{
„Ursprung” - niczym wklęsłe zwierciadło - przywraca całościowy obraz kapitalistycznego sposobu produkcji, niczym (w o wiele większym stopniu niż Schmittiański) Benjaminowski wyjątek, oświetla niektóre z zasadniczych, choć ukrytych właściwości „normalnego” funkcjonowania (Mezzadra 2014, 51).
}

Jedna z tych zasadniczych właściwości jest rola czynników pozaekonomicznych jako integralnych dla funkcjonowania kapitalizmu. W przekonujacy sposób ukazuje to Silvia Federici, przedstawiając w Caliban and the Witch ujęcie akumulacji pierwotnej jako wywłaszczenia na skalę globalną (wywłaszczenia z ziemi w Europie i w koloniach) oraz procesu zarazem ekonomicznego i kulturowego (pojawienie się swoiście kapitalistycznego patriarchatu i rodziny nuklearnej jako instytucji naturalizującej prace reprodukcyjna) (Federici 2004, 75, 107-115). Marks, opisując ustawodawstwo przeciw włóczęgostwu, miał na celu (na długo przed Foucaultem) ukazanie tej samej prawidłowości: wymuszona prawem i/albo kształtowana przez obyczaj dyscyplina jest integralną częścią kapitalistycznego sposobu produkcji (Marks 1968, 872-876).

Kapitalizm jest złożony z heterogenicznych czasowości, a jednocześnie nieustannie dokonuje między nimi pracy synchronizacji. Jednym z wymiarów tej pracy jest linearny schemat rozwoju, którego nie należy lekceważyć jako ideologii (czyli fikcji), bo stanowił/stanowi jedną $z$ technologii władzy (post)kolonialnej (polski dyskurs transformacyjny jest tego najlepszym przykładem).

Progresywizm i historycyzm wpisane są w czasowy kod kapitału (co krytyka musi brać pod uwagę), stanowia jednak wyłącznie jeden z jego wektorów (...) nieustannie odchylany przez gwałtowne (katastroficzne, można by rzec, grając z Benjaminowskimi terminami) otwieranie się na nowo problemu początku (Mezzadra 2014, 73). 
To odchylenie, pojawiające się na skutek złożoności ruchu, dzięki któremu kapitał w nieunikniony sposób staje się kapitalizmem, nie gwarantuje zakwestionowania kapitalistycznej logiki. Myśląc o formach, jakie przybiera walka klas (czy to przejawiająca się w obrębie samego procesu produkcji, czy poza nim), trzeba jednak brać je pod uwagę.

Z powyższych rozważań wynika (mam przynajmniej taką nadzieję), że nie można pojmować uniwersalności kapitału jako wymiaru, który dałby się po prostu oddzielić od empirycznej różnorodności kapitalizmu (oraz, co często za tym idzie, uznawać klasy za a priori możliwą do oddzielenia i ważniejszą od pozostałych wyznaczników statusu). Logika kapitału kształtuje się w toku synchronizacji licznych i często niewspółmiernych czasowości, która narzuca im wspólną miarę; oba wymiary, logika i historia, są częścią jednego procesu, wytwarzającego efekt uniwersalności (który część marksistów bierze za ostateczną rzeczywistość), ale nigdy raz na zawsze, i zawsze kosztem pojawienia się nowych miejsc, w których może zaistnieć to, co niewspółmierne wobec kapitalistycznej synchronizacji. Owo zakwestionowanie podziału na logikę i historię, strukturę i genezę, kapitał i kapitalizm ukazuje również, że marksizm i poststrukturalizm moga - mimo wzajemnych uprzedzeń i nieporozumień - wiele sobie nawzajem zaoferować.

Podziękowania: Dziękuję Zbigniewowi Marcinowi Kowalewskiemu, Krystianowi Szadkowskiemu i Michałowi Pospiszylowi za cenne (konstruktywne) uwagi krytyczne do niniejszego tekstu. 


\section{Wykaz literatury}

Althusser, Louis. 2012. O genezie. Tłum. Mateusz Janik. Praktyka Teoretyczna 5: 118-120.

Althusser, Louis i Etienne Balibar. 1975. Cજytanie „Kapitału”. Tłum. Wiktor Dłuski. Warszawa: PIW.

Assorodobraj, Nina. 1946. Poczatki klasy robotniczej: Problem rak roboczych w przemyśle polskim epoki stanistawowskiej. Warszawa: Czytelnik .

Benjamin, Walter. 1996. „O pojęciu historii.” W tegoż, Anioł historii: Eseje, sækice, fragmenty, red. Hubert Orłowski. Tłum. Krystyna Krzemieniowa i in. Poznań: Wydawnictwo Poznańskie.

Chakrabarty, Dipesh. 2011. Prowincjonalizacja Europy. Tłum. Ewa Domańska i in.. Poznań: Wydawnictwo Poznańskie.

Chibber, Vivek. 2013. Postcolonial Theory and the Specter of Capital, London-New York: Verso.

Dirlik, Arif. 1994. “The Postcolonial Aura.” Critical Inquiry 20: 328-356.

Federici, Silvia. 2004. Caliban and the Witch. New York: Autonomedia.

Foucault, Michel. 2000. „Nietzsche, genealogia, historia.” Tłum. Damian Leszczyński i Lotar Rasiński. W tegoż, Filozofia, historia, polityka. Warszawa: PWN.

Goldmann, Lucien. 1978. „Geneza i struktura.” W Drogi wspótczesnej filozofii, red. Marek Siemek. Tłum. Andrzej Mencwel. Czytelnik: Warszawa.

Harvey, David. 1982. The Limits to Capital. Oxford: Basil Blackwell.

Harvey, David. 2008. Neoliberalizm. Historia katastrofy. Tłum. Jerzy Paweł Listwan. Warszawa: Książka i Prasa.

Harvey, David. 2010. “The Secret of Primitive Accumulation.” W tegoż, A Companion to Marx's Capital. London: Verso.

Harvey, David. 2011. „Analiza Rzeçy-pospolitej.” Tłum. Piotr Juskowiak, Agnieszka Kowalczyk. Praktyka Teoretyczna 4: .

Harvey David. 2014. Seventeen Contradictions and the End of Capitalism, London: Profile Books.

Harvey David. 2015. „Historia przeciw teorii: Komentarz do Marksowskiej metody z Kapitału.” Tłum. Gabriel Klimont i Jędrzej Malko. Praktyka Teoretycz̨na 2(16): 16-53.

Latour, Bruno. 2011. Nigdy nie bylismy nowocześni. Tłum. Maciej Gdula. Oficyna Naukowa: Warszawa.

Libera Università Metropolitana. 2014. „Pojęcia do przemyślenia.” W Marks. Nowe perspek.tywy, red. Libera Università Metropolitana. Tłum. Sławomir Królak, Warszawa: PWN 2014.

Marks, Karol. 1950. Listy do Kugelmana. Warszawa: Książka i Wiedza.

Marks, Karol. 1968. Kapitał. Tłum. P. Hoffman, B. Minc, E. Lipiński. W Karol Marks, Fryderyk Engels, Drieła, t. 23. Warszawa: Książka i Wiedza.

Mezzadra, Sandro. 2014. „Tak zwana akumulacja pierwotna.” W Marks. Nowe perspektywy, red. Libera Università Metropolitana. Tłum. Sławomir Królak. Warszawa: PWN.

Pospiszyl, Michał. 2013. Ateologia wielości: Katechon, pompa próżniowa i biopolityka. Praktyka Teoretyczina 8. 
Spivak, Chakravorty Gayatri. 2011. Strategie postkolonialne. Tłum. Jakub Majmurek i in. Warszawa: Wydawnictwo Krytyki Politycznej.

Szadkowski, Krystian. 2015. Uniwersytet jako dobro wspólne. Wprowadzenie do krytycznych badań nad sækolnictwem wy:şzym. Warszawa: PWN.

Thompson, E.P. 1966. The Making of the English Working Class. New York: Vintage Books/Random House.

Tomba, Massimiliano. 2011. „Zróżnicowania wartości dodatkowej we współczesnych formach wyzysku." W Wieczna radość, red. Jan Sowa i in. Warszawa: Bęc Zmiana.

Tomba, Massimiliano. 2013. Marx's Temporalities. Tłum. Peter D. Thomas, Sara D. Farris. Leiden-Boston: Brill.

Vinci, Paolo. 2014. „Abstrakcja określona.” W Marks. Nowe perspektywy, red. Libera Università Metropolitana. Tłum. Sławomir Królak. Warszawa: PWN.

Wolf, Eric R. 2009. Europa i ludy bez historii. Tłum. Wojciech Usakiewicz. Kraków: Wydawnictwo Uniwersytetu Jagiellońskiego. 
Joanna Bednarek - filozofka, tłumaczka, członkini redakcji Praktyki Teoretycznej i współpracowniczka Pracowni Pytań Granicznych UAM w Poznaniu, publikowała m.in. w Krytyce Politycznej i Czasie Kultury. Autorka książek: Polityka poza forma: Ontologiczne uwarunkowania poststrukturalistycznej filozofii polityki (2012) i Linie kobiecości: Jak różnica ptciowa przęesztatcita literature i filozofie? (2016).

\section{DANE ADRESOWE:}

Międzywydziałowa „Pracownia Pytań Granicznych” UAM

Collegium Chemicum,

ul. Grunwaldzka 6, 60-780 Poznań, Polska

EMAIL: bednarekjoanna87@gmail.com

CYTOWANIE: Bednarek, Joanna. 2015. „Akumulacja pierwotna i czasowości kapitalizmu.” Praktyka Teoretyczna 2(16): 56-77.

DOI: $10.14746 /$ prt.2015.2.2

\section{AUTHOR: Joanna Bednarek}

TITLE: Primitive Accumulation and Temporalities of Capitalism

ABSTRACT: The main thesis of the article is the statement that capitalism is composed of many different, incoherent temporalities, as well as that apprehension of capitalism from the angle of primitive accumulation enables the more accurate grasp of the modes of its functioning, including the complexity created by the interactions of the temporalities mentionned. The problem of primitive accumulation is, as Sandro Mezzadra proves, a good starting point for analysing this issue. It allows us to pose two questions: first, the question of the relation between the historical dimension and the structural logic of capitalism; second, the question of hierarchical relation between the center and the periphery of the capitalist system. Dipesh Chakrabarty's project of 'provincializing Europe' proves helpful here, as it's goal is deconstruction of the categories of progress, modernization and the capital with its abstract structure. The aim is not to negate the fact that capitalist abstraction is a real force, but to show that this force develops by means of constant assimiliation of the other - redefined as 'backward' or archaic. The linear scheme is in force, because it is the main mechanism of imposing the power of capital; as such, it is not politically neutral.

KEYWORDS: capitalism, history, primitive accumulation, Dipesh Chakrabarty, Massimiliano Tomba 